\title{
Correction to: Bio-economic analysis of super-intensive closed shrimp farming and improvement of management plans: a case study in Japan
}

\author{
Junpei Shinji ${ }^{1}$ - Setsuo Nohara ${ }^{2} \cdot$ Nobuyuki Yagi $^{1} \cdot$ Marcy Wilder $^{3} \mathbb{D}$
}

Published online: 4 April 2020

(c) The Author(s) 2020, corrected publication March 2020

\section{Correction to: Fisheries Science (2019) 85:1055-1065 https://doi.org/10.1007/s12562-019-01357-5}

The article "Bio-economic analysis of super-intensive closed shrimp farming and improvement of management plans: a case study in Japan", written by Junpei Shinji, Setsuo Nohara, Nobuyuki Yagi and Marcy Wilder was originally published electronically on the publisher's internet portal on 17 September 2019 without open access. After publication in volume [85], issue [6], page [1055-1065] with the author(s)' decision to opt for Open Choice the copyright of the article changed on 31st March 2020 to (C) The Author(s) 2020 and the article is forthwith distributed under a Creative Commons Attribution 4.0 International License (https://creativeco mmons.org/licenses/by/4.0/), which permits use, sharing, adaptation, distribution and reproduction in any medium or format, as long as you give appropriate credit to the original author(s) and the source, provide a link to the Creative Commons licence, and indicate if changes were made.

Open Access This article is licensed under a Creative Commons Attribution 4.0 International License, which permits use, sharing, adaptation, distribution and reproduction in any medium or format, as long as you give appropriate credit to the original author(s) and the source, provide a link to the Creative Commons licence, and indicate if changes were made. The images or other third party material in this article are included in the article's Creative Commons licence, unless indicated otherwise in a credit line to the material. If material is not included in the article's Creative Commons licence and your intended use is not permitted by statutory regulation or exceeds the permitted use, you will need to obtain permission directly from the copyright holder. To view a copy of this licence, visit http://creativecommons.org/licenses/by/4.0/.

Publisher's Note Springer Nature remains neutral with regard to jurisdictional claims in published maps and institutional affiliations.

The original article can be found online at https://doi.org/10.1007/ s12562-019-01357-5.

Marcy Wilder

marwil@jircas.affrc.go.jp

1 Department of Global Agricultural Sciences, Graduate School of Agricultural and Life Sciences, The University of Tokyo, 1-1-1 Yayoi, Bunkyo-ku, Tokyo 113-8657, Japan

2 IMT Engineering Inc., 1-23-1 Shinjuku, Shinjuku-ku, Tokyo 160-0022, Japan

3 Japan International Research Center for Agricultural Sciences, 1-1 Ohwashi, Tsukuba, Ibaraki 305-8686, Japan 